\title{
Vertical distribution of planktic foraminifera through an oxygen minimum zone: how assemblages and test morphology reflect oxygen concentrations
}

\author{
Catherine V. Davis ${ }^{1}$, Karen Wishner ${ }^{2}$, Willem Renema ${ }^{3,4}$, and Pincelli M. Hull ${ }^{1,5}$ \\ ${ }^{1}$ Department of Earth and Planetary Sciences, Yale University, New Haven, CT 06511, USA \\ ${ }^{2}$ Graduate School of Oceanography, University of Rhode Island, Narragansett, RI 02882, USA \\ ${ }^{3}$ Department of Ecosystem \& Landscape Dynamics, Institute for Biodiversity \& Ecosystem Dynamics (IBED), \\ University of Amsterdam, Amsterdam, the Netherlands \\ ${ }^{4}$ Naturalis Biodiversity Center, Leiden, the Netherlands \\ ${ }^{5}$ Peabody Museum of Natural History, Yale University, New Haven, 06511, USA
}

Correspondence: Catherine V. Davis (catherine.davis@yale.edu)

Received: 18 July 2020 - Discussion started: 3 August 2020

Revised: 16 December 2020 - Accepted: 4 January 2021 - Published: 10 February 2021

\begin{abstract}
Oxygen-depleted regions of the global ocean are rapidly expanding, with important implications for global biogeochemical cycles. However, our ability to make projections about the future of oxygen in the ocean is limited by a lack of empirical data with which to test and constrain the behavior of global climatic and oceanographic models. We use depth-stratified plankton tows to demonstrate that some species of planktic foraminifera are adapted to life in the heart of the pelagic oxygen minimum zone (OMZ). In particular, we identify two species, Globorotaloides hexagonus and Hastigerina parapelagica, living within the eastern tropical North Pacific OMZ. The tests of the former are preserved in marine sediments and could be used to trace the extent and intensity of low-oxygen pelagic habitats in the fossil record. Additional morphometric analyses of $G$. hexagonus show that tests found in the lowest oxygen environments are larger, more porous, less dense, and have more chambers in the final whorl. The association of this species with the OMZ and the apparent plasticity of its test in response to ambient oxygenation invites the use of $G$. hexagonus tests in sediment cores as potential proxies for both the presence and intensity of overlying OMZs.
\end{abstract}

\section{Introduction}

Oxygenation in the oceans is temporally and spatially variable and is controlled by physical factors like ventilation as well as biotic factors such as photosynthesis and respiration. Oxygen minimum zones (OMZs), where dissolved oxygen can reach undetectable levels, are found in mid-waters (i.e., water depths of hundreds to thousands of meters) in some regions of the global ocean. They are often associated with eastern boundary currents, and other upwelling regions, where surface productivity, and thus sub-surface respiration, is high and ventilation of intermediate waters is low. The presence and extent of dysoxic and anoxic waters and ecosystems have an outsized influence on global biogeochemical cycling (Gruber, 2008; DeVries et al., 2012; Breitburg et al., 2018), making the ongoing expansion and intensification of OMZs (Stramma et al., 2008; Keeling et al., 2009; Stramma et al., 2010; Levin, 2017; Schmidtko et al., 2017; Breitburg et al., 2018) of critical importance to future ocean health. Despite this, there are limited geologic records with which to constrain long-term change in pelagic OMZ environments and, consequently, considerable uncertainty in projections of future OMZs (Stramma et al., 2012; Levin, 2017).

Existing tools for detecting the presence and intensity of OMZs on geological timescales have severe limitations. Proxies for marine oxygenation currently fall into three broad categories: (1) those that are indicative of productivity, nu- 
trient utilization, and preservation, such as carbon accumulation and stable isotopes of carbon and nitrogen; (2) benthic faunal assemblages; and (3) sedimentary indicators such as laminations or accumulation of redox-sensitive trace elements in sediments. Proxies of the first type are indirect indicators of OMZs and cannot deconvolve oxygenation and productivity. Although OMZs are generally associated with highly productive environments today, the formation of an OMZ reflects a combination of factors including source water oxygenation and local processes like nutrient cycling, primary productivity, and organic matter sinking and degradation rates. Proxies of the second and third types function only when a zone of low oxygen intersects the seafloor, which presents a significant geographic limitation. Thus, there is a real need for the development and application of new environmental and oxygenation proxies for OMZs in order to enhance the paleoceanographic toolkit for understanding longterm change in these critical environments.

The tests of planktic foraminifera form the basis of some of the most widely used paleoceanographic proxies for reconstructing past pelagic and near-surface environments (see Kucera, 2007; Katz et al., 2010, for reviews). Here we explore the potential of planktic foraminifera as proxies for the extent and intensity of OMZ environments. Several lines of evidence suggest that planktic foraminifera may occur in low-oxygen environments. Laboratory experiments with the species Orbulina universa and Globigerina bulloides show that both can survive and calcify under low-oxygen conditions (Kuroyanagi et al., 2013), despite living in the ocean mixed layer (e.g., Emiliani, 1954; Fairbanks et al., 1982; Field, 2004; Birch et al., 2013; Wejnert et al., 2013) where they are unlikely to experience sustained low oxygen. Moreover, multiple species have been hypothesized to be lowoxygen specialists: the rarely fossilized species Hastigerina digitata has been observed in situ within low-oxygen waters (Hull et al., 2011), Globorotaloides hexagonus has been collected in plankton tows associated with low-oxygen water masses (Ortiz et al., 1995; Birch et al., 2013), and numerous digitate foraminifers are associated with low-oxygen waters in the fossil record (Coxall et al., 2007). However, without a systematic understanding of species distributions relative to the OMZ, foraminifera-based oxygen proxies can be interpreted only as reflecting a general "sub-surface" environment.

Oxygen minimum zones are home to specialized groups of organisms capable of tolerating low dissolved oxygen levels. A growing body of literature has focused on the distributions of larger zooplankton (e.g., Wishner et al., 1995, 1998; Escribano et al., 2009; Wishner et al., 2013; Maas et al., 2014; Wishner et al., 2018, 2020a), microbial (e.g., Duret et al., 2017; Podlaska et al., 2012; Medina Faull et al., 2020), and viral (Cassman et al., 2012) populations that live and cycle nutrients within the OMZ, but no equivalent study has targeted planktic foraminifera. However, benthic foraminifera are widely understood to be among the ex- tremophiles that thrive in the OMZ through special adaptations (Levin, 2003; Bernhard and Bowser, 2008; Glock et al., 2012, 2018, 2019; LeKieffre et al., 2017; Gooday et al., 2020). Benthic foraminiferal adaptations include nitrate respiration (Risgaard-Petersen et al., 2006; Hogsland et al., 2008; Pina-Ochoa et al., 2010; Bernhard et al., 2011, 2012a, b; Woehle et al., 2018; Orsi et al., 2020), dormancy (Bernhard and Alve, 1996; Ross and Hallock, 2016; LeKieffre et al., 2017), and morphologies consistent with facilitating increased gas exchange (Bernhard, 1986; Perez-Cruz and Machain-Castillo, 1990; Glock et al., 2011, 2012; Kuhnt et al., 2013, 2014; Rathburn et al., 2018). There they are important contributors to benthic food webs (e.g., Nomaki et al., 2008; Enge et al., 2014) and are used as indicators of low-oxygen environments (e.g., Kaiho, 1994; Bernhard et al., 1997; Cannariato et al., 1999; Jorissen et al., 2007; Ohkushi et al., 2013).

The goals of this study are to describe and quantify the abundance of living planktic foraminifera above and within a modern OMZ, to test

1. whether modern planktic foraminifera are present within the OMZ,

2. whether specific species are preferentially or exclusively living within the OMZ, and

3. whether morphological traits of OMZ-dwelling foraminifera reflect oxygenation levels in the environments from which they are recovered.

\section{The eastern tropical North Pacific oxygen minimum zone}

The eastern tropical Pacific is home to the world's largest OMZ, fueled by a combination of high coastal and equatorial productivity and poorly ventilated sub-thermocline waters (Paulmier and Ruiz-Pino, 2009; Fiedler and Talley, 2006). The OMZ in the eastern tropical North Pacific (ETNP) is associated with both a deep particle maximum and a secondary nitrite maximum, indicative of reduction of nitrate to nitrite within the OMZ (Garfield et al., 1983; Buchwald et al., 2015; Medina Faull et al., 2020). The region sampled here is located west of the Baja Peninsula and removed from the regions of greatest surface productivity, towards the northern reaches of the low-oxygen tongue of the ETNP OMZ (Figs. 1 and $\mathrm{S} 1$ in the Supplement).

\section{Methods}

\subsection{Plankton tow collections}

Day and night vertically stratified and horizontal MOCNESS (Multiple Opening/Closing Net and Environmental Sensing System) tows were taken on board the R/V Sikuliaq. An updated MOCNESS system, $1 \mathrm{~m}^{2}$ in diameter, with 


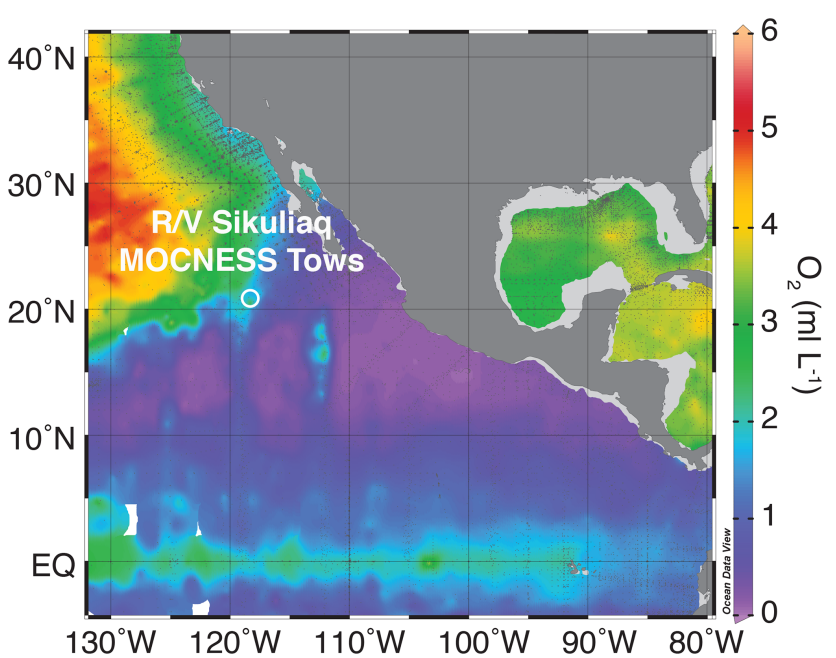

Figure 1. Location of MOCNESS tows (white circle) taken on board the R/V Sikuliaq plotted against a map of dissolved oxygen at $200 \mathrm{~m}$ below the sea surface. Oxygen data are aggregated from the World Ocean Atlas (Garcia et al., 2018) and plotted using Ocean Data Viewer.

$222 \mu \mathrm{m}$ mesh nets, and a Sea-Bird SBE911 conductivitytemperature-depth (CTD) instrument with updated software in place of the original sensors was used (see Wishner et al., 2018). All tows were carried out within relatively close proximity to one another $\left(21^{\circ} \mathrm{N}, 117^{\circ} \mathrm{W}\right)$ between 26 January and 7 February 2017 (Wishner et al., 2018, 2020a, b). This study utilized a total of eight tows, with each tow including the deployment of eight to nine nets to sample a defined depth interval. We use six depth-stratified vertical profiles (nos. 716, 718, 720, 721, 722, 725) that sampled portions of the $0-1000 \mathrm{~m}$ water column and two horizontal tows that sampled the OMZ at $\sim 425 \mathrm{~m}$ depth (nos. 724, 726) (Wishner et al., 2018, 2020a, b). Vertical strata sampled by each net were 25 to $200 \mathrm{~m}$ thick, depending on the tow and depth (see Table S1 in the Supplement or Wishner et al., 2020b, for net strata depths and volume filtered for each net in). In horizontal tows, each net sampled a distance of about $1 \mathrm{~km}$ (Wishner et al., 2018). Environmental data were collected with the MOCNESS CTD sensors simultaneous with plankton collections. For oxygen, a Sea-Bird SBE43 sensor was used. All plankton samples were stored in sodium-borate-buffered seawater and formalin at sea. Isolation of foraminifera from samples occurred in 2017-2019 at the University of Rhode Island. Between 3/10ths and $1 / 125$ th of the material in each net was examined, depending upon abundance of foraminifera, and all intact tests were isolated from the split.

Foraminifera were identified to the species level by light microscope at the University of South Carolina and Yale University. Some tests (9\% of the total observed) were either damaged or, more rarely, appeared to be juvenile forms, such that no species-level identification could be assigned.

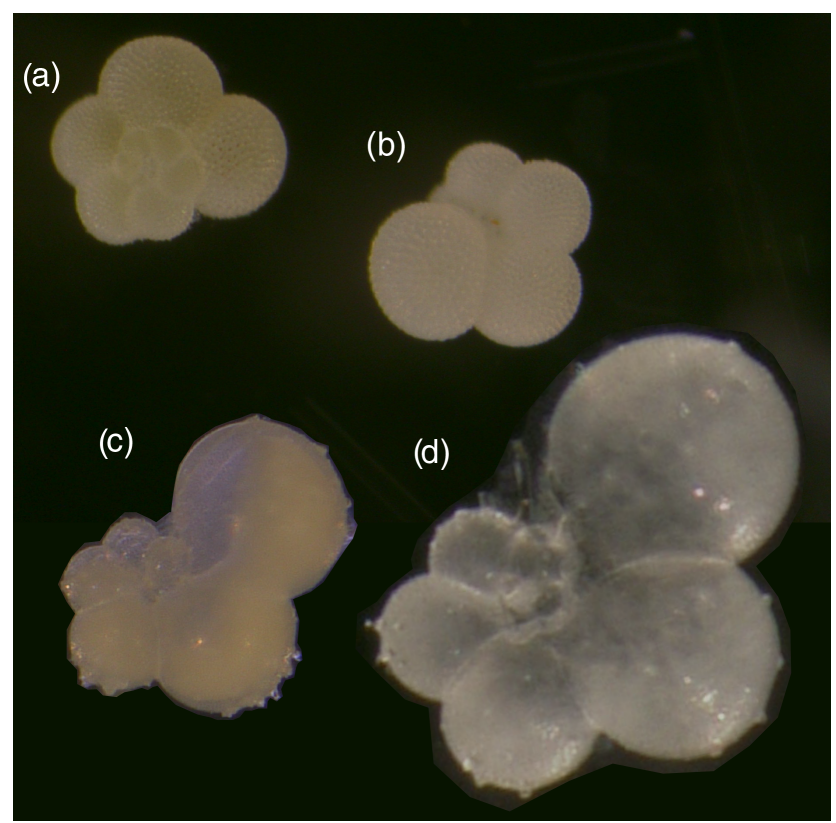

Figure 2. A side-by-side comparison from the same tow of (a) a dorsal view of a live (cytoplasm containing) G. hexagonus and (b) a ventral view of the empty test of $G$. hexagonus, as well as (c) a live and (d) empty $H$. parapelagica.

Due to excellent tissue preservation, the presence or absence of foraminiferal cytoplasm was identifiable, and foraminifera were classified as either "live," based on the presence of cytoplasm, or "dead" in the absence of cytoplasm (Fig. 2). Although preservation was excellent in most tows, some dissolution was observed in three shallow $(<100 \mathrm{~m})$ nets. These have been excluded from further analyses, to prevent skewing assemblages towards more dissolution-resistant taxa. We note that these three nets were exceptionally high in organic matter and that organic matter degradation was the likely cause of dissolution despite buffering and a relatively short storage interval. The organic matter concentration and preservation concerns in these three nets do not apply to the other nets considered in this study.

\subsection{Counting and statistics}

Total counts of foraminifera were adjusted for both the tow split analyzed and the total water volume filtered and are presented as individuals per cubic meter or as relative abundance. Diversity was calculated using the "diversity" function and Shannon index in the R "vegan" package (Oksanen, et al., 2013). All other statistics were carried out in the base package in R (R Core Team, 2017).

\subsection{Morphological analyses}

All individuals of the species $G$. hexagonus were weighed on a Mettler Toledo ultramicrobalance $( \pm 1 \mu \mathrm{g})$ in the Yale 
Analytical and Stable Isotope Center and imaged on a Leica DM6000 light microscope at Yale University. Measurements were made in ImageJ by identifying a flat section of the F (final/ultimate) or F-1 (penultimate) chamber minimally affected by glare and measuring the total area of the section and the total area of section excluding pores. All other morphometric measurements were made using the AutoMorph software (Hsiang et al., 2018).

Porosity is reported as the percentage of test surface area comprised of pores. Size-normalized weight was assessed using the area density method described by Marshall et al. (2013), with the weight of each test normalized to its twodimensional surface area. The compactness of tests was assessed as the ratio of the two-dimensional surface area to the area of a circle (the most compact possible geometry) of the same perimeter. The aspect ratio was defined as the ratio between the height (longest dimension) and width (perpendicular to the longest dimension) as measured in the AutoMorph software (Hsiang et al., 2018). Test size was ascertained by length, surface area, and test perimeter. As surface area and test perimeter were used in deriving compactness and sizenormalized weights, respectively, and all parameters are interrelated, we refer to the longest test dimension when referring to size.

Micro-CT scans were generated at the Naturalis Biodiversity Center using a Zeiss Xradia 520 Versa micro-CT scanner aiming at a voxel size of $0.627 \mu \mathrm{m}$; realized resolution varied from $0.4-0.7 \mu \mathrm{m}$. Scans were made at $90 \mathrm{kV}$ using $20 \times$ optical magnification and were reconstructed using the Zeiss software. Micro-CT scans were processed and analyzed in VG Studio, with volumes assessed by creating a mesh wrap in the MeshLab software (Cignoni et al., 2008) as described in Burke et al. (2020).

\section{Results}

\subsection{Hydrological data from tows}

Plankton tows sampled depths between 0 and $1000 \mathrm{~m}$, across dissolved oxygen levels between 0.03 and $4.93 \mathrm{mLL}^{-1}$ and temperatures ranging from 4.5 to $22.9{ }^{\circ} \mathrm{C}$. Although smallscale oxygen features and their depth relative to the oxycline and OMZ varied somewhat (Wishner et al., 2018, 2020b), the overall structure of the water column was consistent across tows. A warm, oxygenated surface mixed layer overlaid an oxygen-depleted OMZ, with gradual cooling at increasing depth below the thermocline. The upper oxycline (the zone of rapidly decreasing oxygen) was located between 150 and $250 \mathrm{~m}$ water depth, with its upper boundary at the thermocline (Figs. 3-5). Categorization of oxygen levels follows the discussion of Hofmann et al. (2011) and Moffitt et al. (2015). We defined environments with $\left[\mathrm{O}_{2}\right]>2.45 \mathrm{mLL}^{-1}(109 \mu \mathrm{M})$ as oxic, between 2.45 and $1.4 \mathrm{~mL} \mathrm{~L}^{-1}(63 \mu \mathrm{M})$ as transitional ("mild hypoxia" in previous literature), and $<1.4 \mathrm{~mL} \mathrm{~L}^{-1}$ as
OMZ conditions ("hypoxia" and below). Previous authors have distinguished between intermediate $\left(0.5-1.4 \mathrm{~mL} \mathrm{~L}^{-1}\right)$ and severe hypoxia $\left(<0.5 \mathrm{mLL}^{-1} ; 22 \mu \mathrm{M}\right)$, but we have collapsed these to hypoxia as foraminiferal assemblages did not differ between the two categories (see Table S1).

\subsection{Live foraminiferal assemblages}

Assemblages of live foraminifera, described using the definitions of oxygen outlined above, can be divided into three categories: those living in oxic conditions (minimum $\left[\mathrm{O}_{2}\right]$ within a net $>2.45 \mathrm{~mL} \mathrm{~L}^{-1}$ ), OMZ conditions (maximum $\left[\mathrm{O}_{2}\right]$ within a net $<1.4 \mathrm{mLL}^{-1}$ ), and transitional conditions (nets sampling between these two concentrations). The oxic group was the shallowest, with the deepest tow included in this category extending to only $150 \mathrm{~m}$ water depth. These tows had the highest standing stock of foraminifera with 3.4 individuals per cubic meter and the greatest diversity with a mean Shannon index value of 1.3 (ranging from 1.2 to 1.5 across five nets). In this relatively shallow, oxic environment, the assemblage was dominated by Trilobatus sacculifer $(74.6 \%)$ followed by Globigerinoides ruber (5.4\%), Hastigerina pelagica $(5.0 \%)$, Globigerinella siphonifera (4.0\%), Orbulina universa (3.5\%), Globorotaloides hexagonus (3.1\%), and Globigerina bulloides (1.9\%). The species Hastigerina parapelagica, Globorotalia menardii, Globoquadrina conglomerata, Pulleniatina obliquiloculata, and Globorotalia tumida were all found in low abundance $(<1 \%)$ (Table 1; Fig. 6).

Foraminifera from the $\mathrm{OMZ}$ assemblage were found in nets collected below $250 \mathrm{~m}$ water depth and occurred at much lower densities of 0.2 individuals cubic meters. This assemblage was dominated by $G$. hexagonus $(86.1 \%)$, followed by G. sacculifer (3.6\%), H. parapelagica $(2.0 \%)$, H. pelagica $(1.4 \%)$, and G. menardii (0.8\%). The species G. ruber, $O$. universa, G. siphonifera, G. glutinata, G. conglobatus, $P$. obliquiloculata, and G. bulloides were found in low abundance $(<1 \%)$ (Table 1; Fig. 6). The OMZ assemblages were also the least diverse, with a mean Shannon index value of 0.9 (ranging from 0.8 to 1.0 in 54 nets).

The transitional assemblages primarily represented depths between 100 and $250 \mathrm{~m}$ and had the lowest standing stock of foraminifera with 0.1 individuals per cubic meter. There was one net that sampled 800 to $1000 \mathrm{~m}$ and would also fall into this oxygen categorization, but it was excluded from analyses as it contained only a few G. ruber $(<0.01$ individuals per cubic meter) which were likely dead and cannot be readily compared to the upper oxycline habitat of other transitional samples. The transitional assemblage was nearly as diverse as the oxic assemblage with a Shannon index of 1.2 (ranging from 1.1 to 1.2 across four nets). It was composed of G. hexagonus (40.7\%), G. sacculifer (22.1\%), G. siphonifera $(9.6 \%)$, G. conglomerata $(6.4 \%)$, O. universa $(5.5 \%)$, Globorotalia menardii $(5.0 \%)$, H. pelagica $(3.9 \%)$, G. conglobatus $(2.4 \%)$, and S. dehiscens $(1.6 \%)$. A few 


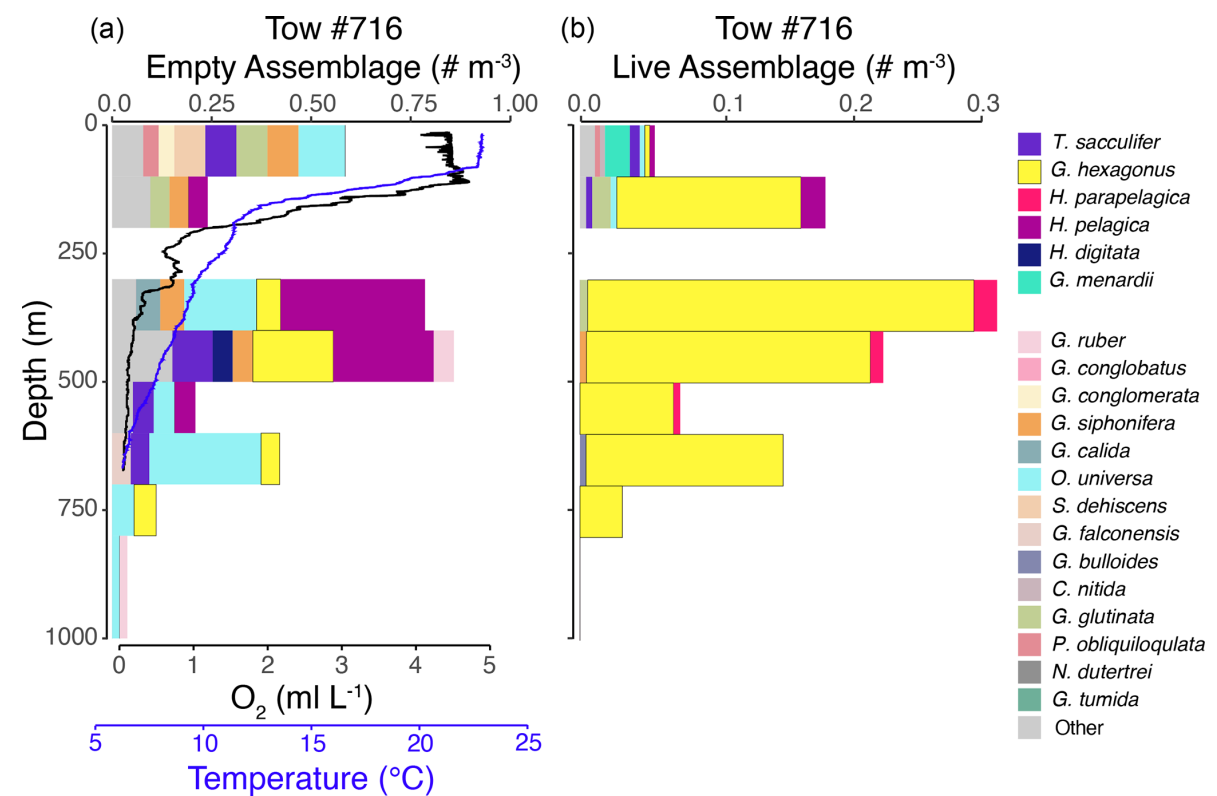

Figure 3. Vertical profiles of the empty assemblage, dissolved oxygen, and temperature (a) and live foraminiferal assemblage (b) from tow no. $716(0-1000 \mathrm{~m})$. Each color represents a different species (see legend), with brighter colors for the six most salient species across nets and depths. Note that the abundance axes vary between panels.

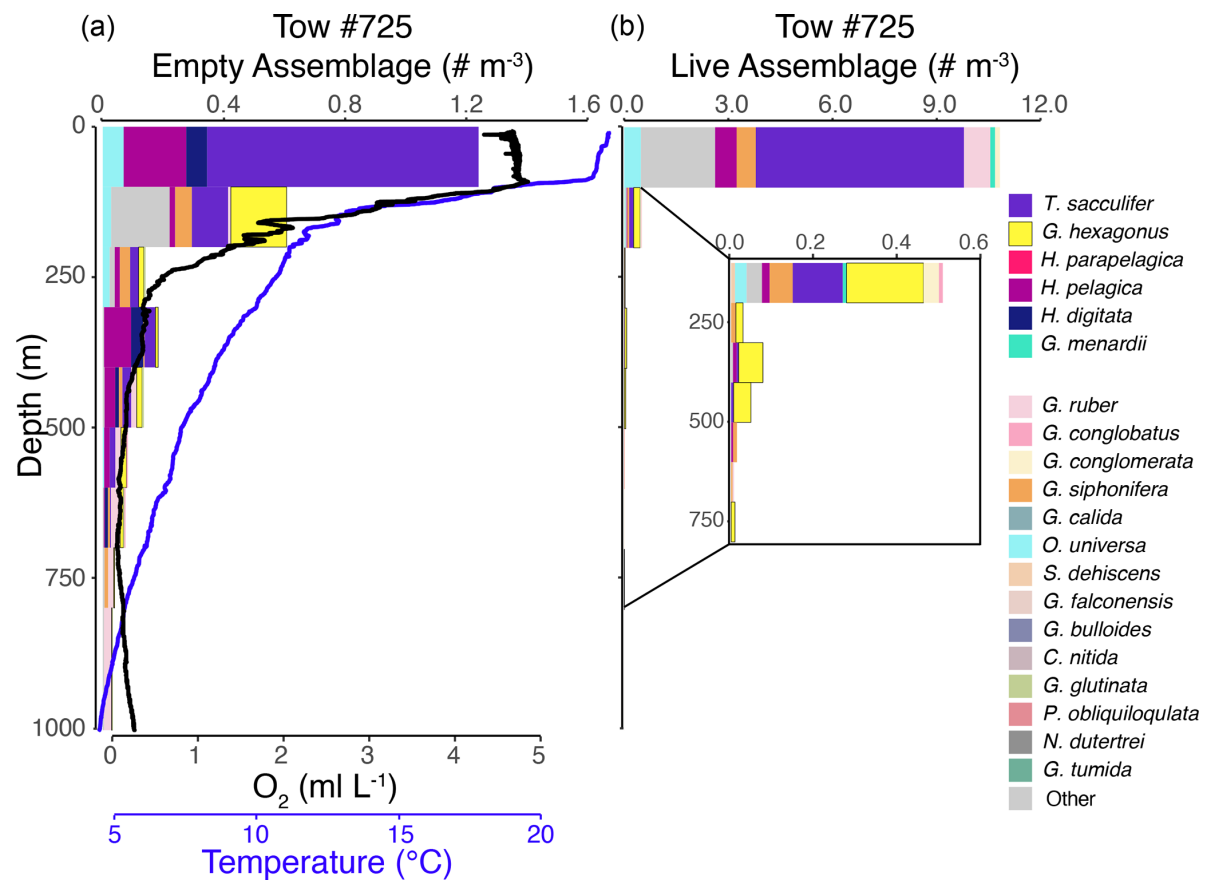

Figure 4. Vertical profiles of the empty assemblage, dissolved oxygen, and temperature (a) and live foraminiferal assemblage (b) from tow no. $725(0-1000 \mathrm{~m})$. Each color represents a different species (see legend). Abundance axes vary, with the inset showing an enlargement of abundance data in that part of the water column. 


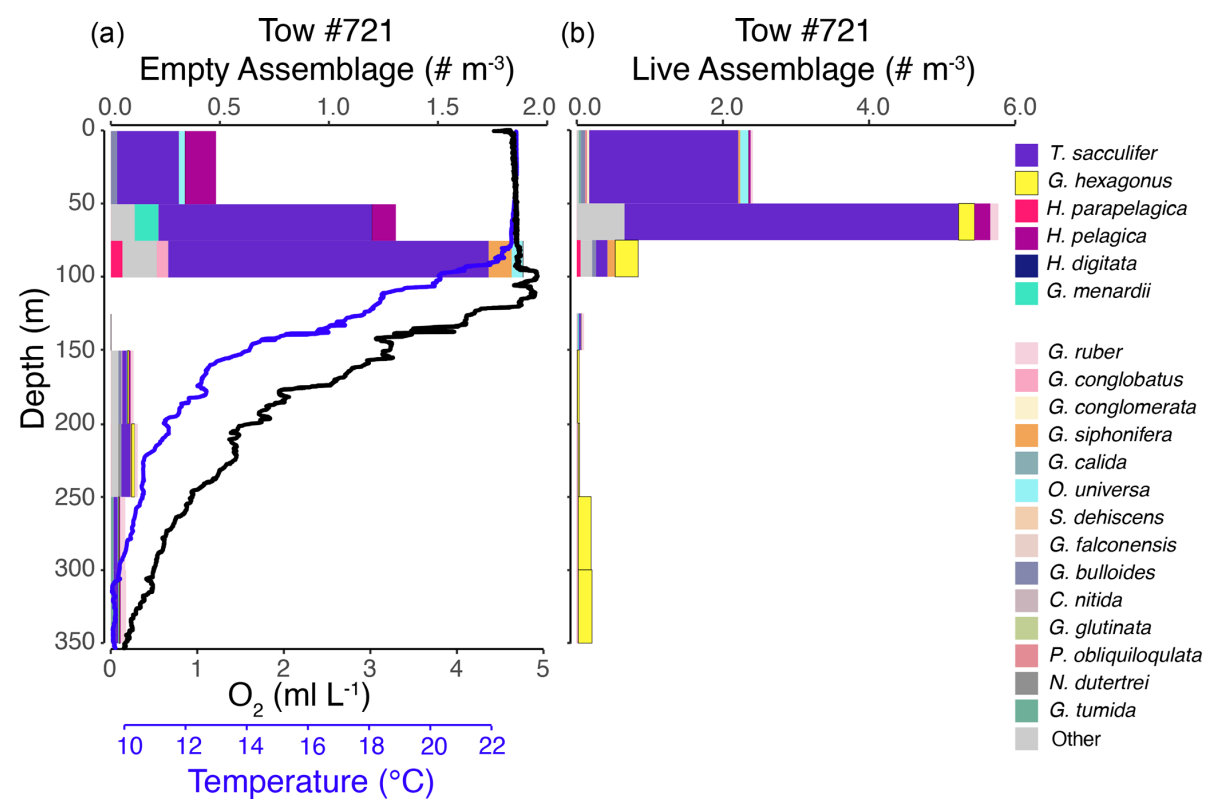

Figure 5. Vertical profiles of the empty assemblage, dissolved oxygen, and temperature (a) and live foraminiferal assemblage (b) from tow no. $721(0-350 \mathrm{~m})$. Each color represents a different species (see legend). Abundance axes vary between panels.

Table 1. The relative abundance of planktic foraminifera within oxygen-defined assemblages: the oxic assemblage (minimum $\mathrm{O}_{2}$ within a net $\mathrm{O}_{2}>2.45 \mathrm{mLL}^{-1}$ ), transitional assemblage, and $\mathrm{OMZ}$ assemblage (maximum $\mathrm{O}_{2}$ within a net $<1.4 \mathrm{mLL}^{-1}$ ).

\begin{tabular}{lrrrr}
\hline Species & $\begin{array}{r}\text { \% of oxic } \\
\text { assemblage }\end{array}$ & $\begin{array}{r}\text { \% of transitional } \\
\text { assemblage }\end{array}$ & $\begin{array}{r}\text { \% of OMZ } \\
\text { assemblage }\end{array}$ & $\begin{array}{r}\text { of empty } \\
\text { shells }\end{array}$ \\
\hline T. sacculifer & 74.6 & 22.1 & 3.6 & 55.4 \\
G. ruber & 5.4 & 0.6 & 0.3 & 6.4 \\
H. pelagica & 5.0 & 3.9 & 1.4 & 11.7 \\
G. siphonifera & 4.0 & 9.6 & 1.0 & 6.0 \\
O. universa & 3.5 & 5.5 & 0.1 & 5.1 \\
G. hexagonus & 3.1 & 40.7 & 86.1 & 5.8 \\
G. bulloides & 1.9 & 0.0 & 0.1 & 1.0 \\
H. parapelagica & 0.3 & 0.8 & 2.0 & 0.0 \\
G. menardii & 0.9 & 5.0 & 0.8 & 1.7 \\
G. conglomerata & 1.0 & 6.4 & 0.1 & 0.2 \\
P. obliquiloculata & 0.2 & 0.7 & 0.7 & 0.4 \\
G. tumida & 0.2 & 0.0 & $<0.1$ & 0.4 \\
G. glutinata & 0.0 & 0.0 & 3.2 & 0.9 \\
H. digitata & 0.0 & 0.0 & 0.0 & 1.9 \\
G. conglobatus & 0.0 & 2.4 & 0.4 & 1.1 \\
S. dehiscens & 0.0 & 1.6 & 0.3 & 0.2 \\
C. nitida & 0.0 & 0.7 & 0.0 & 0.1 \\
G. calida & 0.0 & 0.0 & $<0.1$ & 0.2 \\
G. falconensis & 0.0 & 0.0 & 0.0 & 0.1 \\
N. dutertrei & 0.0 & 0.0 & 0.0 & 0.2 \\
\hline & & & & \\
\hline
\end{tabular}




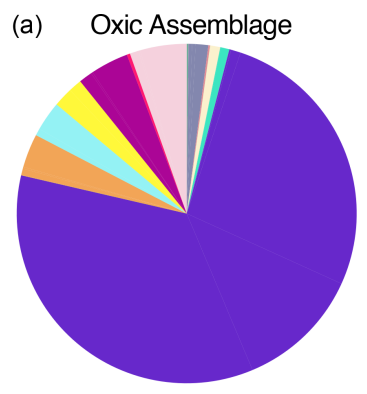

(b) Transitional Assemblage

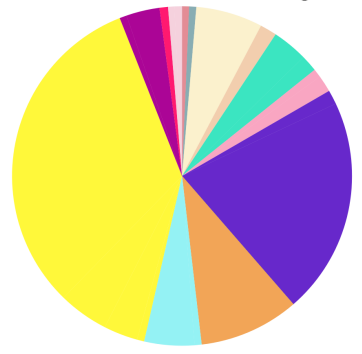

(c) OMZ Assemblage

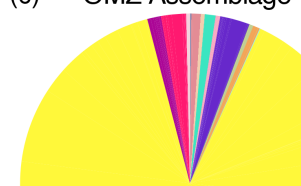

T. sacculifer G. hexagonus H. parapelagica H. pelagica H. digitata G. menardii G. ruber G. conglobatus G. conglomerata G. siphonifera G. calida O. universa S. dehiscens G. falconensis G. bulloides C. nitida G. glutinata P. obliquiloqulata N. dutertrei G. tumida

Figure 6. Pie plots of the live foraminiferal assemblages recovered from oxic nets (minimum dissolved oxygen $>2.45 \mathrm{~mL} \mathrm{~L}^{-1}$; a), transitional nets (b), and OMZ nets (maximum dissolved oxygen $<1.4 \mathrm{~mL} \mathrm{~L}^{-1} ; \mathbf{c}$ ). Each color represents a different species (see legend).

other species, H. parapelagica, C. nitida, G. ruber, and $P$. obliquiloculata, were found in abundances $<1 \%$ (Table 1 ; Fig. 6).

\subsection{Empty test foraminiferal assemblages}

Empty test assemblages mirrored living assemblages, with high species diversity (Shannon index $>1$ ) at depths up to $400 \mathrm{~m}$, after which diversity declined to Shannon index values between 0.5 and 1 . An average of 0.2 empty tests per cubic meter were recovered for all tows. The majority of the empty test assemblage was made up of $G$. sacculifer ( $55.4 \%)$, followed by $H$. pelagica $(11.7 \%)$, G. ruber $(6.4 \%)$, G. siphonifera $(6.0 \%)$, G. hexagonus $(5.8 \%)$, and O. universa $(5.1 \%)$. All other species comprised less than $2 \%$ of the assemblage (Table 1). While every species occurring with cytoplasm was also found without cytoplasm, two species, Hastigerina digitata and Neogloboquadrina dutertrei, were identified in low abundances without cytoplasm but were not observed with cytoplasm.

\subsection{Morphological variation in G. hexagonus}

\subsubsection{Porosity}

Porosity of the most recent chamber in G. hexagonus was highly variable among individuals and among tows, ranging from $1.7 \%$ to $19.4 \%$ of the surface area measured by light microscope. Porosity decreased as oxygen increased, with the clearest relationship between the log of porosity and $\log$ of dissolved oxygen $\left(R^{2}=0.38, p\right.$ value $\left.<0.001\right)$. We chose to focus porosity measurements on the most recent chamber as it was the chamber most likely to have formed under the conditions recorded at collection; however as the foraminifera analyzed had not yet reproduced, it is not possible to know whether this chamber would also have been the terminal chamber, analogous to the final chamber in a fossil shell.

A comparison between porosity of the most recent chamber measured by CT scan and light microscope showed that CT measurements consistently demonstrated higher porosities (Fig. 7). This methodology allowed for non-destructive imaging of the inner test unobscured by later calcite growth, the ability to manipulate test orientation to reduce artifacts of test curvature, and higher resolution, and it should be considered a more accurate measure of test porosity. A direct comparison of the two methods carried out on a subset of tests ( $n=31$ ) showed that the results from the two approaches are correlated $\left(R^{2}=0.37, p\right.$ value $<0.001$; Fig. 7), indicating that the less labor-intensive use of light-microscope measurements captures some of the same trend as the CTbased approach $(y=0.23( \pm 0.05) x+2.64( \pm 1.49))$. While the two methods are comparable in capturing a similar trend, the approaches are distinct enough that measurements by one method (light microscopy) are not sufficient to predict porosity as measured by another (CT scan). Final chamber porosity increased linearly with the size across individuals $\left(R^{2}=0.33, p\right.$ value $\left.<0.001\right)$ and with ontogeny within individuals (Fig. 8), demonstrating a possible relationship between size, ontogeny, and porosity.

\subsubsection{Size and chamber number}

Size decreased with the log of oxygen (Spearman's $\rho=$ $-0.64 ; p$ value $<0.001)$. The largest change in size, as well as the largest change in size-normalized weight and chamber number, occurred as a step change between oxygen levels of 0.1 and $0.2 \mathrm{~mL} \mathrm{~L}^{-1}$ (Fig. 9). The number of chambers visible in the final whorl ranged between four and seven (net means between 4.8 and 6.1), and the largest change in mean chamber number also occurred between 0.1 and $0.2 \mathrm{~mL} \mathrm{~L}^{-1} \mathrm{O}_{2}$, with tests having a greater number of chambers in the final whorl in low-oxygen tows (correlation of 


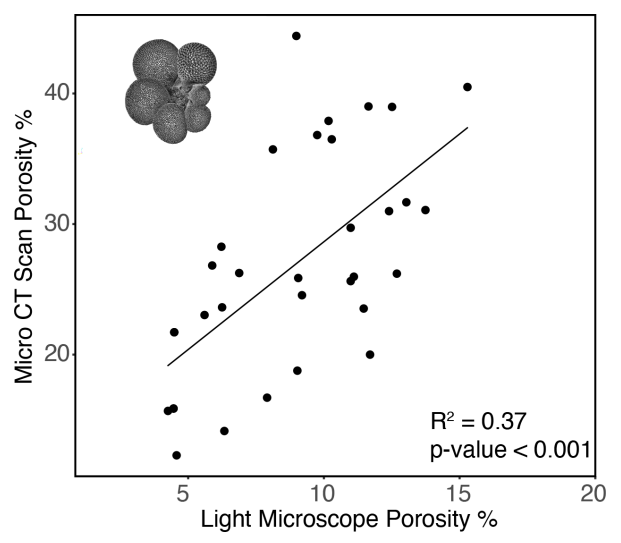

Figure 7. Relationship between $G$. hexagonus final chamber porosity measured by light microscope and CT scan $\left(R^{2}=0.45\right.$, $p$ value $<0.001)$. A representative image reconstructed from CT scanning is inset in the upper left corner.

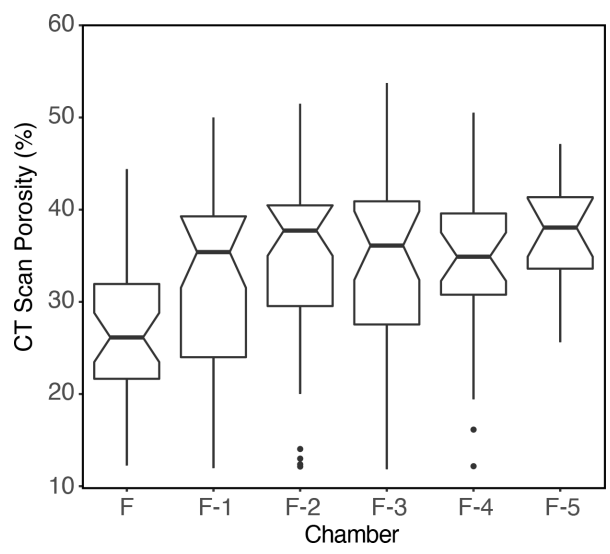

Figure 8. Boxplots of $G$. hexagonus test porosity, determined by inside-out analyses of CT scan images, showing an increase in porosity in the most recently formed $(\mathrm{F})$ chamber.

chamber number to log of average oxygen: Spearman's $\rho=$ $-0.68 ; p$ value $<0.001$; Fig. 9).

\subsubsection{Size-normalized weight}

Globorotaloides hexagonus test weights averaged just $7.7 \mu \mathrm{g}$, ranging from 1 to $22 \mu \mathrm{g}$ for tests between 297 and $631 \mu \mathrm{m}$ in length. Size-normalized weight increased with oxygenation, especially below $0.2 \mathrm{mLL}^{-1} \mathrm{O}_{2}$ (correlation of sizenormalized weight to the log of oxygen: Spearman's $\rho=$ $0.52 ; p$ value $<0.001$; Fig. 9). Size-normalized weight and porosity were correlated $\left(R^{2}=0.34 ; p\right.$ value $\left.<0.001\right)$, as were calcite volume and final chamber porosity measured in CT-scanned foraminifera $\left(R^{2}=0.18 ; p\right.$ value $<0.001$; Fig. S2). Size-normalized weight is also dependent upon size (Henehan et al., 2017), although in our study the variance in size-normalized weight explained by size was low $\left(R^{2}=0.10, p\right.$ value $\left.<0.001\right)$.

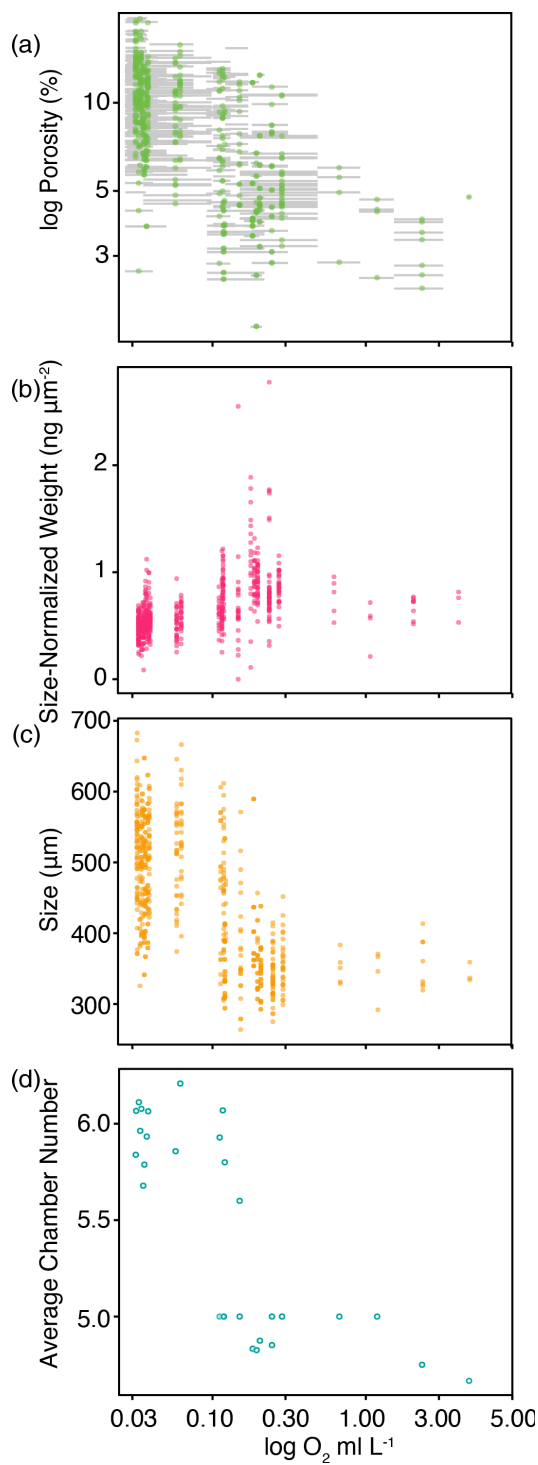

Figure 9. Morphological traits of $G$. hexagonus tests plotted against the average dissolved oxygen (log scale) measured in the nets in which they were collected. The depicted characteristics are (a) log of porosity, (b) size-normalized weight (using the area-density method), (c) size as measured by the longest dimension, and (d) the average number of chambers in the final whorl in a tow. Horizontal gray bars in (a) show the range of oxygen measured for each net.

\subsubsection{Compactness and aspect ratio}

We further tested the utility of test compactness and aspect ratios as potentially diagnostic of the morphological gradient observed. Although test compactness increased linearly with oxygenation $\left(R^{2}=0.03, p\right.$ value $\left.=0.04\right)$ and aspect ratio decreased linearly with the log of oxygen $\left(R^{2}=0.09\right.$, $p$ value $<0.001)$, oxygenation accounted for very little of the variance in either parameter and they were not considered further. 


\section{Discussion}

\subsection{Distinct OMZ community of planktic foraminifera}

Live foraminifera obtained from vertical profiles with depthstratified nets in the ETNP form three distinct pelagic assemblages associated with differing oxygen levels. The OMZ community, living at the lowest oxygen level, was typified by the presence and high relative abundance of the foraminifer G. hexagonus.

The shallow, oxic assemblage $(<150 \mathrm{~m})$ of planktic foraminifera was relatively diverse and included species typical of the Pacific subtropical gyre (Eguchi et al., 1999; Kuroyanagi et al., 2002), with affinities for warmer sea surface temperatures and oligotrophic conditions. However, there was substantial variation between the three tows for which surface assemblages were available (nos. 716, 721, and 725), with abundances in the upper $100 \mathrm{~m}$ varying from $<0.1$ individuals per cubic meter (tow no. 716) to 3.0 individuals per cubic meter (tow no. 721) and 11.0 individuals per cubic meter (tow no. 725) (Figs. 3-5). In the latter two tows the majority of the assemblage was comprised of $T$. sacculifer, whereas in tow no. 716, G. menardii was the most abundant species. A slightly shallower thermocline (compare Figs. 3 to 4 and 5) and deep chlorophyll maximum may be partially responsible for differing abundances. However, there may also be a lunar-associated reproductive response affecting abundance patterns. Tow no. 716 was taken during a waning moon, but tow nos. 721 and 725 were taken during a waxing moon (USNO, 2019). Trilobatus sacculifer reproduces on a lunar cycle, with the largest sizes reached just prior to reproduction during the full moon (Bijma et al., 1990; Erez et al., 1991; Kawahata et al., 2002; Lin, 2010; Jonkers et al., 2015; Venancio et al., 2016). As a result, more individuals large enough $(>222 \mu \mathrm{m})$ to be sampled in our nets may have been present just prior to a full moon (tow nos. 721 and 725).

The OMZ assemblage was dominated by the species $G$. hexagonus, followed by $T$. sacculifer and $H$. parapelagica. Use of presence and absence of cytoplasm as an indicator for living foraminifera results in an overestimation of live individuals, as empty or post-reproductive individuals may retain some cytoplasm while live individuals cannot be devoid of cytoplasm. Thus, despite the presence of $T$. sacculifer in several OMZ samples, it is unlikely that this species, which has photosymbionts and a relatively shallow, photic zone habitat (Fairbanks et al., 1982; Ravelo and Fairbanks, 1992; Schiebel et al., 2004; Regenberg et al., 2009; Birch et al., 2013; Rebotim et al., 2017), was resident in the deep OMZ. It is more likely that cytoplasm-bearing tests of $T$. sacculifer found below the photic zone are a consequence of their very high abundance in the surface ocean and reflected premature mortality and/or the retention of some cytoplasm following reproduction. On the other hand, $G$. hexagonus and $H$. parapelagica comprised $88.1 \%$ of cytoplasm-bearing tests in OMZ nets, while only being found in low abundances in surface assemblages. This suggests that these two species are truly endemic to deeper hypoxic waters.

The transitional assemblage was a mix between the welloxygenated surface assemblage, with abundant $T$. sacculifer, and the deeper OMZ assemblage, composed primarily of $G$. hexagonus. This mix of species was almost certainly an artifact of the depth (and oxygen) range integrated within a single net (50-100 m thick strata) through the steep oxycline. However, the transitional assemblage also had two unique characteristics. The first was the presence of deeper-dwelling taxa, such as $G$. conglomerata and $G$. menardii, which were rare in most other nets. The second was the exceptionally low standing stock of planktic foraminifera (mean of 0.1 individual per cubic meter across four tows; Figs. 3-5). The low density of foraminifera in the oxycline is an interesting contrast to the vertical distributions of many metazoan species that often peak in abundance in the upper oxycline and decline in the core of the OMZ (Maas et al., 2014; Wishner et al., 1995, 2013, 2020b). Based on the mixed assemblage and low densities, we hypothesize that planktic foraminifera are largely absent from the upper oxycline, with populations restricted to either the oxygenated photic zone habitat above or the OMZ below. Whether this distributional pattern is related to physiological constraints, food resources, predation pressure, physical oceanographic mechanisms, or other environmental parameters is unknown, and future sampling at higher vertical resolution through the oxycline is required to test these hypotheses.

\subsection{Globorotaloides hexagonus as an OMZ indicator species}

Globorotaloides hexagonus was consistently found within our low-oxygen nets, though individuals were sparsely distributed (mean density of 0.2 individual per cubic meter), with peak abundances between 300-500 $\mathrm{m}$ depth in the core of the OMZ (Figs. 3-5 and S3-S5). There was no evidence of diel vertical migration when comparing distributions in tows taken during the day (nos. 718, 722, 724, 725, 726) and night (nos. 716, 720,721), in agreement with the lack of diel vertical migration observed in shallow-dwelling species (Meilland et al., 2019). Absence of large-scale migrations and a preference for oxygen-depleted habitats indicate that the species is adapted to live for long periods of time, likely its entire lifespan, within low-oxygen conditions.

Globorotaloides hexagonus has previously been associated with deep, low-oxygen water masses across the IndoPacific, including the eastern North Pacific (Sautter and Thunell, 1991; Ortiz et al., 1996; Davis et al., 2016), equatorial Pacific (Fairbanks et al., 1982; Rippert et al., 2016; Max et al., 2017; Rippert et al., 2017), Peru-Chile margin (Marchant et al., 1998), and Indian Ocean (Rao et al., 1989; Schiebel et al., 2004; Birch et al., 2013). The species is sometimes assumed to be extinct in the Atlantic, with recent iden- 
tifications of $G$. hexagonus in Atlantic sediments explicitly used to date sediments as pre-Holocene or ascribed to taxonomic error (e.g., Kucera et al., 2005; Siccha and Kucera, 2017). However, the assumption of a basin-wide extinction appears poorly supported, and G. hexagonus tests were isolated from deep (500-3200 m) Atlantic sediment traps as recently as 2009-2013 (Smart et al., 2018). We hypothesize that $G$. hexagonus occupies low-oxygen mid-waters globally (i.e., in the Atlantic as well as the Indo-Pacific) but that its deep habitat and low abundance have biased observations away from identifications of $G$. hexagonus in the modern Atlantic. However, additional evidence, such as molecular genetics, may be required to finally resolve this question. Altogether, the geographic distribution, presence of cytoplasm-bearing $G$. hexagonus in OMZ tows, and scarcity of $G$. hexagonus above the oxycline strongly suggest that $G$. hexagonus lives preferentially, or even exclusively, within the OMZ. This species can be considered an indicator of an OMZ habitat and may be useful as an OMZ marker in sedimentary records.

We also found a second, less abundant, species, H. parapelagica, in association with low-oxygen waters. This same morphology was previously observed in situ in low-oxygen waters by Hull et al. (2011), and more recently by Gaskell et al. (2019), referred to as "Hastigerina spp." by the former and "Hastigerina pelagica" by the latter. Given the depth distribution and morphological variation observed here for $H$. parapelagica, we suspect that it is synonymous with the globally distributed "Hastigerina pelagica" genotype IIa, described by Weiner et al. (2012) and use the name Hastigerina parapelagica (Saito et al., 1976) as the senior synonym of Hastigerina pelagica genotype IIa (Weiner et al. 2012).

\subsection{Morphological variation in G. hexagonus reflects water column oxygenation}

Globorotaloides hexagonus shares several morphological traits with low-oxygen-associated benthic foraminifera including a flattened whorl maximizing its surface area / volume ratio at a given size and large pores (e.g., Bernhard, 1986). Both characters could serve to increase gas exchange and fulfill metabolic requirements in an oxygenlimited environment (Leutenegger and Hansen, 1979; Corliss, 1985). Unlike some digitate planktic foraminifera previously associated with deep and oxygen-depleted environments (Hull et al., 2011; Coxall et al., 2007; Gaskell et al., 2019), G. hexagonus is non-spinose, which may suggest that it is herbivorous or bacterivorous as described for other non-spinose foraminifera (Schiebel and Hemleben, 2017; Bird et al., 2018), rather than dependent on live zooplankton as prey.

The tests of $G$. hexagonus in deeper, less oxygenated waters appeared more porous, larger, and less compact than those from shallower, more oxygenated environments. These observations, and the presence of $G$. hexagonus across a wide range of depths and oxygenation levels, led us to quantify the environmental correlates of morphological variation in porosity, size-normalized weight, size, chamber number, and shape as potential proxies in paleo-environmental reconstructions. A high test porosity and high pore density have been widely associated with low-oxygen environments in benthic foraminifera (Bernhard, 1986; Perez-Cruz and Machain-Castillo, 1990; Glock et al., 2011, 2012; Kuhnt et al., 2013, 2014; Rathburn et al., 2018) and in cultured planktic foraminifera (Kuroyanagi et al., 2013). These characteristics may play a role in facilitating gas exchange (Leutenegger and Hansen, 1979; Corliss, 1985) and may represent a balance between the need for gas exchange and structural constraints (Richirt et al., 2019). However, increased porosity has also been associated with other parameters: increasing temperature (Bijma et al., 1990; Burke et al., 2018), decreasing nitrate availability (Glock et al., 2011, 2018), and increasing test size (Burke et al., 2018). In the OMZ samples where G. hexagonus was found, porosity increased with both decreasing oxygen concentration and increasing test size, with the lowest oxygen conditions hosting the largest and most porous tests (Fig. 9). In contrast to this trend, porosity decreases through ontogeny in $G$. hexagonus, with the most recent chamber being less porous than earlier chambers (Fig. 8). While the presence of a relationship between porosity of $G$. hexagonus and oxygenation is clear in our data set, future efforts to quantify this relationship should target a population of exclusively post-reproductive individuals, using both light microscopy and CT imaging in addition to scanning electron microscopy of the inner test walls. Neither temperature nor nitrate availability (used by some benthic foraminifera as an alternative terminal proton acceptor in very low-oxygen environments; Risgaard-Petersen et al., 2006; Hogslund et al., 2008; Pina-Ochoa et al., 2010; Bernhard et al., 2011, 2012a, b; Woehle et al., 2018), are likely to drive the observed variation in porosity as temperature was nearly constant $\left(7.7-8.5^{\circ} \mathrm{C}\right)$ across samples and nitrate availability increases with depth in the region (Podlaska et al., 2012; Buchwald et al., 2015; Medina Faull et al., 2020).

Tests collected at lower oxygen levels also had lower size-normalized weights, a property which negatively correlates with porosity. Size-normalized weight in planktic foraminifera has frequently been associated with changes in carbonate chemistry (i.e., Bijma et al., 2002; Russell et al., 2004; Marshall et al., 2013). As oxygen and DIC (dissolved inorganic carbon) depth profiles in the ocean are inversely related, the OMZ is also a region of exceptionally high DIC (Paulmier et al., 2008, 2011). While no carbonate chemistry measurements are available in conjunction with our tows, calcite saturation state at equivalent latitudes in the eastern tropical South Pacific OMZ approaches 1, below which calcite dissolution is favored (Bates, 2018). Both an increase in porosity and a decrease in size-normalized weight (whether due to porosity, a decrease in test thickness, or a combination of factors) are consistent with a reduction of overall calcifica- 

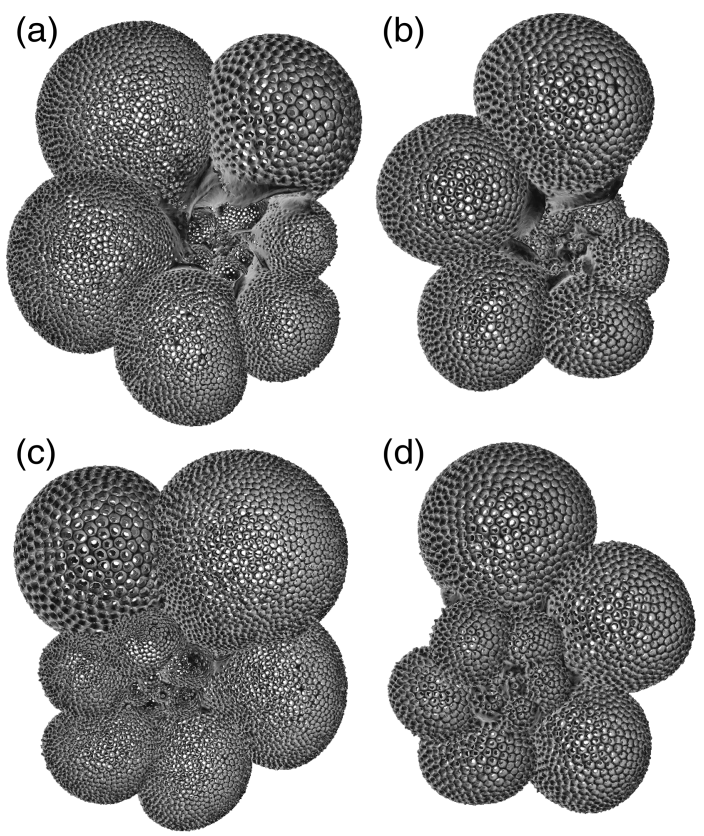

Figure 10. Examples of G. hexagonus tests from tow no. 716 imaged by micro-CT scan, showing (a) a more porous six-chambered individual recovered deeper in the $\mathrm{OMZ}$ and (b) a less porous five-chambered individuals captured shallower in the OMZ. Dorsal views of the same two specimens are shown in (c) and (d), and both represent typical rather than extreme examples along the continuum of morphological diversity observed.

tion in low-calcite-saturation states associated with the OMZ, where precipitation and maintenance of a test may be more metabolically expensive.

Tests collected from the lowest oxygen conditions were less compact with more chambers visible in the final whorl (Fig. 10). The addition of more lobes via increased chamber number has the effect of increasing the surface area / volume ratio for a given size, which could facilitate increased gas exchange via diffusion. However, the increase in size with decreased oxygen availability is such that larger $G$. hexagonus in low-oxygen environments would still have lower surface / volume ratios than smaller individuals from more oxygenated environments (Fig. S6). It may be that increased porosity in larger individuals is able to partially compensate for this decrease in surface area / volume ratios.

Although the increase in size at low oxygen levels appears enigmatic, there are several potential reasons for this pattern. First, surface area increases with size, which could be beneficial for increasing encounters with food. Larger sizes could also result from delayed reproduction at lower oxygen levels. Alternatively, increased size (cell volume) has been associated with greater capacity for denitrification in some benthic foraminifera (Glock et al., 2019). An inconsistent relationship between surface area / volume ratios and oxygenation has also been observed in several facultative anaer- obic species of benthic foraminifera, with only two of the four species studied showing the expected decrease in size with decreasing oxygen levels (Keating-Bitonti and Payne, 2017). Whether G. hexagonus possesses physiological strategies that allow it to function as a facultative anaerobe cannot be determined at this point. However, the combination of increased size (potentially indicative of anaerobic strategies) and increased porosity and morphologies apparently optimized for increasing aerobic capacity in low-oxygen environments suggests a complex physiology. A decrease in porosity with ontogeny could even hint at a shift in physiology over the lifespan of an individual (Fig. 8). Further unraveling the environmental pressures driving test morphology in $G$. hexagonus will require a greater understanding of the species' ecology.

\section{Conclusions}

Vertically stratified plankton tows taken through the eastern tropical North Pacific show that distinct assemblages of planktic foraminifera live above and within the OMZ and that a depauperate fauna occupies the upper oxycline. Two species, G. hexagonus and H. parapelagica, were found living preferentially or exclusively within the OMZ. Several aspects of test morphology in $G$. hexagonus varied in response to ambient oxygen levels. Some morphological features may be associated with facilitating gas exchange (i.e., porosity, chamber arrangement) or decreasing expenditure on calcification (size-normalized weight, porosity) under the lowoxygen and/or carbonate saturation state conditions of the OMZ. The function of other morphological trends, like size, remain enigmatic. Abundance patterns and the co-variation in specific morphological features with oxygenation levels in G. hexagonus tests could be used to reconstruct changes in OMZ environments, providing an additional proxy record of the mid-water OMZ in which these foraminifera lived. As the species appears to be living primarily in the OMZ, recovery of $G$. hexagonus tests from sediments would be a strong indication of low-oxygen mid-waters. Moreover, large tests with high porosity, low size-normalized weight, and more chambers in the final whorl could be interpreted as having calcified closer to the core of the OMZ than their smaller, less porous conspecifics.

Data availability. All data associated with this article are available in the Supplement or have been previously published and archived on the BCO-DMO database found at http://lod.bco-dmo. org/id/dataset/755088 (Wishner et al., 2020a).

Supplement. The supplement related to this article is available online at: https://doi.org/10.5194/bg-18-977-2021-supplement. 
Author contributions. CVD conceived of the study, CVD and WR carried out analyses, and KW and PMH provided resources. CVD prepared the original draft manuscript, and all authors contributed to writing and editing.

Competing interests. The authors declare that they have no conflict of interest.

Acknowledgements. Many thanks to Dawn Outram for laboratory assistance, to Robert C. Thunell (deceased) for invaluable support in the genesis of this project, and to Ralf Schiebel and the anonymous reviewer for their comments on the manuscript.

Financial support. This research was supported by NSF OCE 1851589 to Catherine V. Davis, NSF OCE 1459243 to Karen Wishner, and a Sloan Research Fellowship to Pincelli M. Hull.

Review statement. This paper was edited by Markus Kienast and reviewed by Ralf Schiebel and one anonymous referee.

\section{References}

Bates, N. R.: Seawater carbonate chemistry distributions across the Eastern South Pacific Ocean sampled as part of the GEOTRACES project and changes in marine carbonate chemistry over the past 20 years, Front. Mar. Sci., 5, 398, https://doi.org/10.3389/fmars.2018.00398, 2018.

Bernhard, J. M.: Characteristic assemblages and Morphologies of benthic foraminifera from anoxic, organic-rich deposits: Jurassic through Holocene, J. Foramin. Res., 16, 207-215, 1986.

Bernhard, J. M. and Alve, E.: Survival, ATP pool, and ultrastructural characterization of benthic foraminifera from Drammensfjord (Norwar): response to anoxia, Mar. Micropaleontol., 28, 5-17, 1996.

Bernhard, J. M. and Bowser, S. S.: Peroxisome proliferation in Foraminifera inhabiting the chemocline: an adaptation to reactive oxygen species exposure?, J. Eukaryot. Microbiol., 55, 135-144, 2008.

Bernhard J. M., Sen Gupta, B. K., and Borne, P. F.: Benthic foraminiferal proxy to estimate dysoxic bottom-water oxygen concentrations; Santa Barbara Basin, US Pacific continental margin, J. Foramin. Res., 27, 301-310, 1997.

Bernhard, J. M., Edgcomb, V. P., Casciotti, K. L., McIlvin, M. R., and Beaudoin, D. J.: Dentrification likely catalyzed by endobionts in an allogromiid foraminifer, ISME J., 6, 951-960, 2011.

Bernhard, J. M., Edgcomb, V. P., Casciotti, K. L., McIlvin, M. R., and Beaudoin, D. J.: Denitrification likely catalyzed by endobionts in an allogromiid foraminifer, ISME J., 6, 951960, https://doi.org/10.1038/ismej.2011.171, 2012a.

Bernhard, J. M., Casciotti, K. L., McIlvin, M. R., Beaudoin, D. J., Visscher, P. T., and Edgcomb, V. P.: Potential importance of physiologically diverse benthic foraminifera in sedimentary nitrate storage and respiration, J. Geophys. Res.-Biogeo., 117, G03002, https://doi.org/10.1029/2012JG001949, 2012b.

Bijma, J., Faber, W. W., and Hemleben, C.: Lunar and semi-lunar reproductive cycles in some spinose planktonic foraminifers, J. Foramin. Res., 20, 117-127, 1990.

Bijma, J., Faber, W. W., and Hemleben, C: Temperature and salinity limits for growth and survival of some planktonic foraminfiers in laboratory cultures, J. Foramin. Res., 20, 95-116, 1990.

Bijma, J., Honisch, B., and Zeebe, R. E.: Impact of the ocean carbonate chemistry on living foraminiferal shell weght: Comment on "Carbonate ion concentration in glacia-age deep waters of the Caribbean Sea" by W. S. Broecker and E. Clark, Geochem. Geophy. Geosy., 3, 1-7, 2002.

Birch, H., Coxall, H. K., Pearson, P. N., Kroon, D., and O'Regan, M.: Planktonic foraminifera stable isotopes and water column structure: Disentangling ecological signals, Mar. Micropaleontol., 101, 127-145, 2013.

Bird, C., Darling, K. F., Russell, A. D., Fehrenbacher, J. S., Davis, C. V., Free, A., and Ngwenya, B. T.: 16S rRNA gene metabarcoding and TEM reveals different ecological strategies within the genus Neogloboquadrina (planktonic foraminifer), PloS one, 13, e0191653, https://doi.org/10.1371/journal.pone.0191653, 2018.

Breitburg, D., Levin, L. A., Oschlies, A., Gregoire, M., Chavez, F. P., Conley, D. J., Garcon, V., Gilbert, D., Gutierrez, D., Isensee, K., Jacinto, G. S., Limburg, K. E., Montes, I., Naqvi, S. W. A., Pitcher, G. C., Rabalais, N. N., Roman, M. R., Rose, K. A., Seibel, B. A., Telszewski, M., Yasuhara, M., and Zhang, J.: Declining oxygen in the global ocean and coastal waters, Science, 359, eaam7240, https://doi.org/10.1126/science.aam7240, 2018.

Buchwald, C., Santoro, A. E., Stanley, R. H. R., and Casciotti, K. L.: Nitrogen cycling in the secondary nitrite maximum of the eastern tropical North Pacific off Coasta Rica, Global Biogeochem. Cy., 29, 1656-1673, https://doi.org/10.1002/2015GB005198, 2015.

Burke, J. E., Renema, W., Henehan, M. J., Elder, L. E., Davis, C. V., Maas, A. E., Foster, G. L., Schiebel, R., and Hull, P. M.: Factors influencing test porosity in planktonic foraminifera, Biogeosciences, 15, 6607-6619, https://doi.org/10.5194/bg-156607-2018, 2018.

Burke, J. E., Renema, W., Schiebel, R., and Hull, P. M.: Three-dimensional analysis of inter-and intraspecific variation in ontogenetic growth trajectories of planktonic foraminifera, Mar. Micropaleontol., 155, 101794, https://doi.org/10.1016/j.marmicro.2019.101794, 2020.

Cannariato, K. G., Kennett, J. P., and Behl, R. J.: Biotic response to late Quaternary rapid climate switches in Santa Barbara Basin: Ecological and evolutionary implications, Geology, 27, 63-66, 1999.

Cassman, N., Prieto-Davo, A., Walsh, K., Silva, G. G. Z., Angly, F., Akhter, S., Barott, K., Busch, J., McDole, T., Haggerty, J. M., Willner, D., Alarcon, G., Ulloa, O., DeLong, E. F., Dutilh, B. E., Rohwer, F., and Dinsdale, E. A.: Oxygen minimum zones harbor novel viral communities with low diversity, Environ. Microbiol., 14, 3043-3065, 2012.

Cignoni, P., Callieri, M., Corsini, M., Dellepiane, M., Ganovelli, F., and Ranzuglia, G.: MeshLab: an open-source mesh processing tool, in: Proceedings of the Sixth Eurographics Italian Chapter Conference, 2-4 July 2008, Salerno, Italy, 129-136, 2008.

Corliss, B. H.: Microhabitats of benthic foraminifera within deepsea sediments, Nature, 314, 435-439, 1985. 
Coxall, H. K., Pearson, P. N., Wilson, P. A., and Sexton, P. F.: Iterative evolution of digitate planktonic foraminifera, Paleobiology, 33, 495-516, 2007.

Davis, C. V., Hill, T. M., Russell, A. D., Gaylord, B., and Jahncke, J.: Seasonality in planktic foraminifera of the central California coastal upwelling region, Biogeosciences, 13, 5139-5150, https://doi.org/10.5194/bg-13-5139-2016, 2016.

DeVries, T., Deutsch, C., Primeau, F., Chang, B., and Devol, A.: Global rates of water-column denitrification derived from nitrogen gas measurements, Nature Geosci., 5, 547, https://doi.org/10.1038/ngeo1515, 2012.

Duret, M. T., Pachiadaki, M. G., Stewart, F. J., Sarode, N., Christaki, U., Mochy, S., Srivastava, A., and Edgcomb, V. P.: Size-fractionated diversity of eukaryotic microbial communities in the Eastern Tropical North Pacific oxygen minimum zone, FEMS Microbiol. Ecol., 91, fiv037, https://doi.org/10.1093/femsec/fiv037, 2017.

Eguchi, N. O., Kawahata, H., and Asahiko, T.: Seasonal Response of Planktonic Foraminifera to surface ocean conditions: Sediment trap results from the Central North Pacific Ocean, J. Oceanogr., 55, 681-691, 1999.

Emiliani, C.: Depth habitats of some species of pelagic foraminifera as indicated by oxygen isotopic ratios, Am. J. Sci., 252, 149-158, 1954.

Enge, A. J., Witte, U., Kucera, M., and Heinz, P.: Uptake of phytodetritus by benthic foraminifera under oxygen depletion at the Indian margin (Arabian Sea), Biogeosciences, 11, 2017-2026, https://doi.org/10.5194/bg-11-2017-2014, 2014.

Erez, J., Almogi-Labin, A., and Avraham, S.: On the life history of planktonic foraminifera: Lunar reproduction cycle in Globigerinoides sacculifer (Brady), Paleoceanography, 6, 295-306, 1991.

Escribano, R., Hidalgo, P., and Krautz, C.: Zooplankton associated with the oxygen minimum zone system in the northern upwelling region of Chile during March 2000, Deep-Sea Res., 56, 10831094, 2009.

Fairbanks, R. G., Sverdlove, M., Free, R., Wiebe, P. H., and Be, A. W. H.: Vertical distribution and isotopic fractionation of living planktonic foraminifera from the Panama Basin, Nature, 298, 841-844, 1982.

Fiedler, P. C. and Talley, L. D.: Hydrography of the eastern tropical Pacific: A Review, Prog. Oceanogr. 69, 143-180, 2006.

Field, D. B.: Variability in vertical distributions of planktonic foraminifera in the California Current: Relationships to vertical ocean structure, Paleoceanography, 19, PA2014, https://doi.org/10.1029/2003PA000970, 2004.

Garcia, H. E., Weathers, K., Paver, C. R., Smolyar, I., Boyer, T. P., Locarnini, R. A., Zweng, M. M., Mishonov, A. V., Baranova, O K., Seidov, D., and Reagan, J. R.: World Ocean Atlas 2018, Dissolved Oxygen, Apparent Oxygen Utilization, and Oxygen Saturation, NOAA, Silver Spring, USA, 2018.

Garfield, P. C., Packard, T. T., Friederich, G. E., and Codispoti, L. A.: A subsurface particle maximum layer and enhanced microbial activity in the secondary nitrate maximum of the northeastern tropical Pacific Ocean, J. Mar. Res., 41, 747-768, 1983.

Gaskell, D. E., Ohman, M. D., and Hull, P. M.: Zooglider-based measurements of planktonic foraminifera in the California Current system, J. Foramin. Res., 49, 390-404, 2019

Glock, N., Eisenhauer, A., Milker, Y., Liebetrau, V., Schonfeld, J., Mallon, J., Sommer, S., and Hensen, C.: Environmental in- fluences on the pore density of Bolivina spissa (Cushman), J. Foramin. Res., 41, 22-32, 2011.

Glock, N., Schönfeld, J., and Mallon, J.: The Functionality of Pores in Benthic Foraminifera in View of Bottom Water Oxygenation: A Review, in: Anoxia, Cellular Origin, Life in Extreme Habitats and Astrobiology, edited by: Altenbach, A. V., Bernhard, J. M., and Seckbach, J., Springer, the Netherlands, 537-552, 2012.

Glock, N., Erdem, Z., Wallmann, K., Somes, C. J., Liebetrau, V., Schonfeld, J., Gorb, S., and Eisenhauer, A.: Coupling of oceanic carbon and nitrogen facilitates spatially resolved quantitative reconstruction of nitrate inventories, Nat. Commun., 9, 1217, https://doi.org/10.1038/s41467-018-03647-5, 2018.

Glock, N., Roy, A. S., Romero, D., Wein, T., Weissenbach, J., Revsbech, N. P., Hogslund, S., Clemens, D., Sommer, S., and Dagan, $\mathrm{T}$ : Metabolic preference of nitrate over oxygen as an electron acceptor in foraminifera from the Peruvian oxygen minimum zone, P. Natl. Acad. Sci. USA, 116, 2860-2865, 2019.

Gooday, A. J., Bernhard, J. M., Levin, L. A., and Suhr, S. B.: Foraminifera in the Arabian Sea oxygen minimum zone and other oxygen-deficient settings: taxonomic composition, diversity, and relation to metazoan faunas, Deep-Sea Res., 47, 25-54, 2000.

Gooday, A. J., Schoenle, A., Dolan, J. R., and Arndt, H.: Protist diversity and function in the dark ocean - Challenging the paradigms of deep-sea ecology with special emphasis on foraminiferans and naked protists, Eur. J. Protistol., 75, 125721, https://doi.org/10.1016/j.ejop.2020.125721, 2020.

Gruber, N.: The marine nitrogen cycle: overview and challenges, Nitrogen in the marine environment, 2, 1-50, Academic Press Cambridge, MA, USA, 2008.

Henehan, M. J., Evans, D., Shankle, M., Burke, J. E., Foster, G. L., Anagnostou, E., Chalk, T. B., Stewart, J. A., Alt, C. H. S., Durrant, J., and Hull, P. M.: Size-dependent response of foraminiferal calcification to seawater carbonate chemistry, Biogeosciences, 14, 3287-3308, https://doi.org/10.5194/bg-14-3287-2017, 2017.

Hofmann, A. F., Peltzer, E. T., Walz, P. M., and Brewer, P. G.: Hypoxia by degrees: Establishing definitions for a changing ocean, Deep-Sea Res., 58, 1212-1226, 2011.

Hogslund, S., Revsbech, N. P., Cedhagen, T., Nielsen, L. P., and Gallardo, V. A.: Denitrification, nitrate turnover, and aerobic respiration by benthic foraminiferans in the oxygen minimum zone off Chile, J. Exp. Mar. Biol. Ecol., 39, 85-91, 2008.

Hsiang, A. Y., Nelson, K., Elder, L. E., Sibert, E. C., Kahanamoku, S. S., Burke, J. E., Kelly, A., Liu, Y., and Hull, P. M.: Automorph: Accelerating morphometrics with automated 2D and 3D image processing and shape extraction, Methods Ecol. Evol., 9, 605612, 2018.

Hull, P. M., Osborn, K. J., Norris, R. D., and Robison, B. H.: Seasonality and depth distribution of a mesopelagic foraminifer, Hastigerinella digitata, in Monterey Bay, California, Limnol. Oceanogr. 56, 562-576, 2011.

Jonkers, L., Reynolds, C. E., Richey, J., and Hall, I. R.: Lunar periodicity in the shell flux of planktonic foraminifera in the Gulf of Mexico, Biogeosciences, 12, 3061-3070, https://doi.org/10.5194/bg-12-3061-2015, 2015.

Jorissen, F. J., Fontanier, C., and Thomas, E.: Chapter seven paleoceanographical proxies based on deep-sea benthic foraminiferal assemblage characteristics, Developments in Marine Geology, 1, 263-325, 2007. 
Kaiho, K.: Benthic foraminiferal dissolved-oxygen index and dissolved-oxygen levels in the modern ocean, Geology, 22, 719722, 1994.

Katz, M. E., Cramer, B. S., Franzese, A., Hönisch, B., Miller, K. G., Rosenthal, Y., and Wright, J. D.: Traditional and emerging geochemical proxies in foraminifera, J. Foramin. Res., 40, 165192, 2010.

Kawahata, H., Nichimura, A., and Gagan, M. K.: Seasonal change in foraminiferal production in the western equatorial Pacific warm pool: evidence from sediment trap experiments, Deep-Sea Res., 49, 2783-2800, 2002.

Keating-Bitonti, C. R. and Payne, J. L.: Ecophenotypic responses of benthic foraminifera to oxygen availability along an oxygen gradient in the California Borderland, Mar. Ecol., 38, e12430, https://doi.org/10.1111/maec.12430, 2017.

Keeling, R. F., Körtzinger, A., and Gruber, N.: Ocean Deoxygenation in a Warming World, Annu. Rev. Mar. Sci., 2, 199-229, 2009.

Kucera, M.: Chapter six planktonic foraminifera as tracers of past oceanic environments, Developments in Marine Geology, 1, 213-262, 2007.

Kucera, M., Weinelt, M., Kiefer, T., Pflaumann, U., Hayes, A., Weinelt, M., Chen, M.-T., Mix, A. C., Barrows, T. T., Cortijo, E., Duprat, J., Juggins, S., and Waelbroech, C.: Reconstruction of sea-surface temperatures from assemblages of planktonic foraminifera: multi-technique approach based on geographically constrained calibration data sets and its application to glacial Atlantic and Pacific Oceans, Quaternary Sci. Rev., 24, 951-998, 2005.

Kuhnt, T., Friedrich, O., Schmiedl, G., Milker, Y., Machensen, A., and Luckge, A.: Relationship between pore density in benthic foraminifera and bottom-water oxygen content, Deep-Sea Res., 76, 85-96, 2013.

Kuhnt, T., Schiebel, R., Schmiedl, G., Milker, Y., Mackensen, A., and Friedrich, O.: Automated and manual analyses of the pore density-to-oxygen relationship in Globobulimina turgida (Baily), J. Foramin. Res., 44, 1-5, 2014.

Kuroyanagi, A., Kawahata, H., Nishi, H., and Hondo, M. C.: Seasonal changes in planktonic foraminifera in the northwestern North Pacific Ocean: sediment trap experiments from subarctis and subtropical gyres, Deep-Sea Res., 49, 5627-5645, 2002.

Kuroyanagi, A., da Rocha, R. E., Bijma, J., Spero, H. J., Russell, A. D., Eggins, S. M., and Kawahata, H.: Effect of dissolved oxygen concentration on planktonic foraminifera through laboratory culture experiments and implications for oceanic anoxic events, Mar. Micropaleontol., 101, 28-32, 2013.

LeKieffre, C., Spangenberg, J. E., Mabilleau, G., Escrig, S., Meibom, A., and Geslin, E.: Surviving anoxia in marine sediments: The metabolic response of ubiquitous benthic foraminifera (Ammonia tepida), PloS One, 12, e0177604, https://doi.org/10.1371/journal.pone.0177604, 2017.

Leutenegger, S. and Hansen, H. J.: Ultrastructural and radiotracer studies of pore function in Foraminifera, Mar. Biol., 54, 11-16, 1979.

Levin, L. A.: Oxygen minimum zone benthos: Adaptation and community response to hypoxia, Oceanogr. Mar. Biol., 41, 1-45, 2003.

Levin, L. A.: Manifestation, Drivers, and Emergence of Open Ocean Deoxygenation, Annu. Rev. Mar. Sci., 10, 229-260, 2017.
Lin, H.: The seasonal succession of modern planktonic foraminfiera: Sediment traps observations from southwest Taiwan waters, Cont. Shelf Res., 84, 13-22, 2010.

Maas, A. E., Frazar, S. L., Outram, D. M., Seibel, B. A., and Wishner, K. F.: Fine-scale vertical distribution of macroplankton and micronekton in the Eastern Tropical North Pacific in association with an oxygen minimum zone, J. Plankton Res., 36, 1557-1575, 2014.

Marchant, M., Hebbeln, D., and Wefer, G.: Seasonal flux patterns of planktic foraminifera in the Peru-Chile Current, Deep-Sea Res., 45, 1161-1185, 1998.

Marshall, B. J., Thunell, R. C., Henehan, M. J., Astor, Y., and Wejnert, K. E.: Planktonic foraminiferal area density as a proxy for carbonate ion concentration: A calibration study using the Cariaco Basin ocean time series, Paleoceanography, 28, 363-376, 2013.

Max, L., Rippert, N., Lembke-Jene, L., Mackensen, A., Nurnberg, D., and Tiedemann, R.: Evidence for enhanced convection of North Pacific Intermediate Water to the low? latitude Pacific under glacial conditions, Paleoceanogr. Paleocl. 32, 41-55, 2017.

Medina Faull, L., Mara, P., Taylor, G. T., and Edgcomb, V. P.: Imprint of trace dissolved oxygen on prokaryoplankton community structure in an Oxygen Minimumz Zone, Front. Mar. Sci., 7, 360, https://doi.org/10.3389/fmars.2020.00360, 2020.

Meiland, J., Siccha, M., Weinkauf, M. F. G., Jonkers, L., Morard, R., Baranowski, U., Baumeister, A., Bertlich, J., Brummer, G.-J., Debray, P., Fritz-Endres, T., Groeneveld, J., Magerl, L., Munz, P., Rillo, M. C., Schmidt, C., Takagi, H., Theara, G., and Kucera, M.: Highly replicated sampling reveals no diurnal vertical migration but stable species-specific vertical habitats in planktonic foraminifera, J. Plankton Res., 41, 127-141, 2019.

Moffitt, S. E., Moffitt, R. A., Sauthoff, W., Davis, C. V., Hewett, K., and Hill, T. M.: Paleoceanographic insights on recent oxygen minimum zone expansion: Lessons for modern oceanography, PloS One, 10, e0115246, https://doi.org/10.1371/journal.pone.0115246, 2015.

Nomaki, H., Ogawa, N. O, Ohkouchi, N., Suga, H., Toyofuku, T., Shimanaga, M., Nakatsuka, T., and Kitazato, H.: Benthic foraminifera as trophic links between phytodetritus and benthic metazoans: carbon and nitrogen isotopic evidence, Mar. Ecol.Prog. Ser., 357, 153-164, 2008.

Ohkushi, K., Kennett, J. P., Zeleski, C. M., Moffitt, S. E., Hill, T. M., Robert, C., Beaufort, L., and Behl, R. J.: Quantified intermediate water oxygenation history of the NE Pacific: A new benthic foraminiferal record from Santa Barbara basin, Paleoceanography, 28, 453-467, 2013.

Oksanen, J., Blanchet, F. G., Kindt, R., Legendre, P., Minchin, P. R., O'hara, R. B., Simpson, G. L., Solymos, P., Stevens, M. H. H., and Wagner, H.: Package "vegan", Community ecology package, version, 2, 1-295, 2013.

Orsi, W. D., Morard, R., Vuillemin, A., Eitel, M., Worheide, G., Milucka, J., and Kucera, M.: Anaerobic metabolism of Foraminifera thriving below the seafloor, ISME J., 14, 25802594, 2020.

Ortiz, J. D., Mix, A. C., and Collier, R. W.: Environmental control of living symbiotic and asymbiotic foraminifera of the California Current, Paleoceanography, 10, 987-1009, 1995.

Ortiz, J. D., Mix, A., Rugh, W., Watkins, J., and Collier, R.: Deep-dwelling planktonic foraminifera of the northeastern Pa- 
cific Ocean reveal environmental control of oxygen and carbon isotopic disequilibria, Geochim. Cosmochim. Ac., 60, 45094523, 1996.

Paulmier, A. and Ruiz-Pino, D.: Oxygen minimum zones (OMZs) in the modern ocean, Prog. Oceanogr., 80, 113-128, 2009.

Paulmier, A., Ruiz-Pino, D., and Garçon, V.: The Oxygen Minimum Zone (OMZ) off Chile as intense source of $\mathrm{CO}_{2}$ and $\mathrm{N}_{2} \mathrm{O}$, Cont. Shelf Res., 28, 2746-2756, 2008.

Paulmier, A., Ruiz-Pino, D., and Garçon, V.: $\mathrm{CO}_{2}$ maximum in the oxygen minimum zone (OMZ), Biogeosciences, 8, 239-252, https://doi.org/10.5194/bg-8-239-2011, 2011.

Perez-Cruz, L. L. and Machain-Castillo, M. L.: Benthic foraminifera of the oxygen minimum zone, continental shelf of the Gulf of Tehuantepec, Mexico, J. Foramin. Res., 20, $312-325,1990$.

Pina-Ocoa, E., Hogslund, S., Geslin, E., Cedhagen, T., Revsbech, N. P., Nielse, L. P., Schweizer, M., Jorissen, F., Rysgaard, S., Risgaard-Petersen, N., and Canfield, D. E.: Widespread occurrence of nitrate storage and denitrification among Foraminifera and Gromiida, P. Natl. Acad. Sci. USA, 107, 1148-1153, 2010.

Podlaska, A., Wakeham, S. G., Fanning, K. A., and Taylor, G. T.: Microbial community structure and productivity in the oxygen minimum zone of the eastern tropical North Pacific, Deep-Sea Res., 66, 77-89, 2012.

Rao, K. K., Jayalakshmy, K. V., Kumaran, S., Balasubramanian, T., and Kutty, M. K.: Planktonic foraminifera in waters off the Coromandel coast, Bay of Bengal, Indian J. Mar. Sci., 18, 1-7, 1989.

Rathburn, A. E., Willingham, J., Ziebis, W., Burkett, A. M., and Corliss, B. H.: A new biological proxy for deep-sea paleooxygen: Pores of epifaunal benthic foraminifera, Sci. Rep., 8, 9456, https://doi.org/10.1038/s41598-018-27793-4, 2018.

Ravelo, A. C. and Fairbanks, R. G.: Oxygen isotopic composition of multiple species of planktonic foraminfera: Recorders of the modern photic zone temperature, Paleoceanography, 7, 815-831, 1992.

R Core Team: A language and environment for statistical computing, R Foundation for Statistical Computing, Vienna, Austria, 2017.

Rebotim, A., Voelker, A. H. L., Jonkers, L., Waniek, J. J., Meggers, H., Schiebel, R., Fraile, I., Schulz, M., and Kucera, M.: Factors controlling the depth habitat of planktonic foraminifera in the subtropical eastern North Atlantic, Biogeosciences, 14, 827-859, https://doi.org/10.5194/bg-14-827-2017, 2017

Regenberg, M., Steph, S., Nurnberg, D., Tiedemann, R., and GarbeSchonberg, D.: Calibrating Mg / Ca ratios of multiple planktonic foraminiferal species with $\delta^{18} \mathrm{O}$-calcification temperatures: Paleothermometry for the upper water column, Earth Planet. Sc. Lett., 278, 324-336, 2009.

Richirt, J., Champmartin, S., Schweizer, M., Mouret, A., Petersen, J., Ambari, A., and Jorissen, F. J.: Scaling laws explain foraminiferal pore patterns, Sci. Rep., 9, 9149, https://doi.org/10.1038/s41598-019-45617-x, 2019.

Rippert, N., Nurnberg, D., Raddatz, J., Maier, E., Hathorne, E. C., Bijma, J., and Tiedemann, R.: Constraining foraminiferal calcification depths in the western Pacific warm pool, Mar. Micropaleontol., 128, 14-27, 2016.

Rippert, N., Max, L., Mackensen, A., Cacho, I., Povea, P., and Tiedemann, R.: Alternating influence of northern versus southern-sourced water masses on the equatorial Pacific subthermocline during the past $240 \mathrm{ka}$, Paleoceanogr. Paleocl., 32, 1256-1274, 2017.

Risgaard-Petersen, N., Langezaal, A. M., Ingvardsen, S., Schmid, M. C., Jetten, M. S. M., Op den Camp, H. J. M., Derksen, J. W. M., Pina-Ochoa, E., Eriksson, S. P., Nielsen, L. P., Revsbech, N. P., Cedhagen, T., and van der Zwaan, G. J.: Evidence for complete denitrification in a benthic foraminifer, Nature, 443, 93-97, 2006.

Ross, B. J. and Hallock, P.: Dormancy in the Foraminfiera: A review, J. Foramin. Res., 46, 358-368, 2016.

Russell, A. D., Honisch, B., Spero, H. J., and Lea, D. W.: Effects of seawater carbonate ion concentration and temperature on shell $\mathrm{U}$, $\mathrm{Mg}$, and $\mathrm{Sr}$ in cultured planktonic foraminifera, Geochim. Cosmochim. Ac., 68, 4347-4361, 2004.

Saito, T., Thompson, P. R., and Breger, D.: Skeletal ultramicrostructure of some elongate chambered planktonic foraminifera and related species, in: Progress in Micropaleontology, edited by: Takayanagi, Y. and Saito, T., American Museum of Natural History, New York, NY, USA, 278-304, 1976.

Sautter, L. R. and Thunell, R. C.: Seasonal variability in the $\delta^{18} \mathrm{O}$ and $\delta^{13} \mathrm{C}$ of planktic foraminifera from an upwelling environments: sediment trap results from the San Pedro Basin, Southern California Bight, Paleoceanography, 6, 307-334, 1991.

Schiebel, R. and Hemleben, C.: Planktic foraminifers in the modern ocean, Springer, Berlin, Germany, 2017.

Schiebel, R., Zeltner, A., Treppke, U. F., Waniek, J. J., Bollmann, J., Rixen, T., and Hemleben, C.: Distribution of diatoms, coccolithophores and planktic foraminifers along a trophic gradient during SW monsoon in the Arabian Sea, Mar. Micropaleontol., 3/4, 345-371, 2004.

Schmidtko, S., Stramma, L., and Visbeck, M.: Decline in global oceanic oxygen content during the past five decades, Nature, 542, 335-339, 2017.

Siccha, M. and Kucera, M.: ForCenS, a curated database of planktonic foraminifera census counts in marine surface sediment samples, Sci. Data, 4, 170109, https://doi.org/10.1594/PANGAEA.873570, 2017.

Smart, S. M., Ren, H., Fawcett, S. E., Schiebel, R., Conte, M., Rafter, P. A., Ellis, K. K., Weigand, M. A., Oleynik, S., Haug, G. H., and Sigman, D. M.: Ground-truthing the planktic foraminifer-bound nitrogen isotope paleo-proxy in the Sargasso Sea, Geochim. Cosmochim. Ac., 235, 463-482 2018.

Stramma, L., Johnson, G. C., Sprintall, J., and Mohrholz, V.: Expanding Oxygen-Minimum Zones in the Tropical Oceans, Science, 320, 655-658, 2008.

Stramma, L., Johnson, G. C., Firing, E., and Schmidtko, S.: Eastern Pacific oxygen minimum zones: Supply paths and multidecadal changes, J. Geophys. Res.-Oceans, 115, C09011, https://doi.org/10.1029/2009JC005976, 2010.

Stramma, L., Prince, E. D., Schmidtko, S., Luo, J., Hoolihan, J. P., Visbeck, M., Wallace, D. W. R., Brandt, R., and Kortzinger, A.: Expansion of oxygen minimum zones may reduce available habitat for tropical pelagic fishes, Nat. Clim. Change, 2, 33-37, 2012.

USNO: USNO Astronomical Applications Department, available at: http://aa.usno.navy.mil/data/docs/MoonPhase.php, last access: 10 October 2019.

Venancio, I. M., Franco, D., Belem, A. L., Mulitza, S., Siccha, M., Albuquerue, A. L. S., Schulz, M., and Kucera, M.: Planktonic 
foraminifera shell fluxes from a weekly resolved sediment trap record in the southwestern Atlantic: Evidence for synchronized reproduction, Mar. Micropaleontol., 125, 25-35, 2016.

Weiner, A., Aurahs, R., Kurasawa, A., Kitazato, H., and Kucera, M.: Vertical niche partitioning between cryptic sibling species of a cosmopolitan marine planktonic protist, Mol. Ecol., 21, 40634073, 2012.

Wejnert, K. E., Thunell, R. C., and Astor, Y.: Comparison of species-specific oxygen isotope paleotemperature equations: Sensitivity analysis using planktonic foraminifera from the Cariaco Basin, Venezuela, Mar. Micropaleontol., 101, 76-88, 2013.

Wishner, K. F., Ashjian, C. J., Gelfmann, C., Gowing, M. M., Kann, L., Levin, L. A., Mullineaux, L. S., and Saltzman, J.: Pelagic and benthic ecology of the lower interface of the Eastern Tropical Pacific oxygen minimum zone, Deep-Sea Res., 42, 93-115, 1995.

Wishner, K. F., Gowing, M. M., and Gelfman, C.: Mesozooplankton biomass in the upper $1000 \mathrm{~m}$ in the Arabian Sea: overall seasonal and geographic patterns, and relationship to oxygen gradients, Deep-Sea Res., 45, 2405-2432, 1998.

Wishner, K. F., Outram, D. M., Seibel, B. A., Daly, K. L., and Williams, R. L.: Zooplankton in the eastern tropical north Pacific: Boundary effects of oxygen minimum zone expansion, Deep-Sea Res., 79, 122-140, 2013.
Wishner, K. F., Seibel, B. A., Roman, C., Deutsch, C., Outram, D., Shaw, C. T., Birk, M. A., Mislan, K. A. S., Adams, T. J., Moore, D., and Riley, S.: Ocean deoxygenation and zooplankton: Very small oxygen differences matter, Sci. Adv., 4, eaau5180, https://doi.org/10.1126/sciadv.aau5180, 2018.

Wishner, K. F., Seibel, B., and Roman, C.: Event log from R/V Sikuliaq SKQ201701S from January to February 2017, Biological and Chemical Oceanography Data Management Office (BCODMO), available at: http://lod.bco-dmo.org/id/dataset/755088, last access: 27 May 2020a.

Wishner, K. F., Seibel, B., and Outram, D.: Ocean deoxygenation and copepods: coping with oxygen minimum zone variability, Biogeosciences, 17, 2315-2339, https://doi.org/10.5194/bg-172315-2020, 2020b.

Woehle, C., Roy, A.-S., Glock, N., Wein, T., Weissenbach, J., Rosenstiel, P., Hiebenthal, C., Michels, J., Schonfeld, J., and Dagan, T.: A novel eukaryotic denitrification pathway in foraminifera, Curr. Biol., 28, 2536-2543, 2018. 